\title{
Quality Changes in Cantaloupe During Growth, Maturation, and in Stored Fresh-cut Cubes Prepared from Fruit Harvested at Various Maturities
}

\author{
John C. Beaulieu' ${ }^{1}$ and Jeanne M. Lea \\ United States Department of Agriculture, Agricultural Research Service, Southern \\ Regional Research Center, 1100 Robert E. Lee Boulevard, New Orleans, LA 70124
}

\begin{abstract}
Additional Index words. Cucumis melo, firmness, fructose, gas chromatography, GC, glucose, maturity, melon, soluble solids, sucrose, texture, vitamin C

Abstract. Cantaloupe (Cucumis melo L. var. reticulatus Naudin) were evaluated during development and then freshcut cubes were stored after preparation from various maturities to track quality changes during storage. Flowers were anthesis tagged one morning in two seasons (years) and developing fruit were harvested weekly at 13, 20, 27 to 28, and 34 to 35 days after anthesis (DAA). Mature fruit were harvested at 37 to 38 DAA with five distinct maturities: 1/4-, 1/2-, 3/4-slip, full-slip (FS), and overripe (OR). Hunter $L^{*}$ and $a^{*}$ color values indicated a change from pale green to light orange that occurred 28 DAA. There were significant decreases in $L^{*}, a^{*}$, and $b^{*}$ by day 9 in storage $\left(4^{\circ} \mathrm{C}\right)$ as fresh-cut cubes. After 28 DAA, sucrose dramatically increased, and this was positively correlated with increases in both total sugars $(r=0.882, P=0.084)$ and percent soluble solids concentration $(r=0.939, P=0.041)$. Gradual deterioration occurred during storage, as determined by a uniform subjective quality criterion, which was independent of maturity. There was a negative linear trend in hand-held and instrumental firmness over the length of storage for each maturity level, and the slopes decreased significantly with increasing maturity, indicating the effect of storage duration decreased as harvest maturity increased. There was a significant increasing trend in vitamin $C$ $(P=0.042)$ during development from 12 through 35 DAA, then losses were greater in fresh-cut cubes prepared from full-slip fruit (65\%) than less-mature fruit: 3/4-slip, 50\%; 1/2-slip, 48\%; 1/4-slip, 40\%. The pH of mesocarp tissue dropped to the lowest value (5.25) just before physiological maturity at 27 to $28 \mathrm{DAA}$, then peaked after harvest (6.51-6.79), and declined somewhat by the end of storage as fresh-cut cubes. In sum, muskmelon fruit used to produce fresh-cut cubes should be harvested $\geq 1 / 2$-slip to attain optimum physiological quality and consumer acceptability.
\end{abstract}

In muskmelon, development of an abscission layer between the vine and fruit at the peduncle is a good indicator of full ripeness and harvest time. Fruit harvested before development of the abscission zone will not develop quality, volatile, and flavor attributes similar to fruit that remained on the vine until fully ripe (Beaulieu, 2006; Beaulieu and Grimm, 2001; Beaulieu et al., 2004; Pratt, 1971; Wyllie et al., 1996). However, fruit harvested at or after development of the abscission have a shorter storage life, and flavor or textural loss may occur before completion of the marketing process (Evensen, 1983; Hoover, 1955; Ogle and Christopher, 1957). Muskmelons are highly regarded for their unique flavor, and high sugar levels [soluble solids concentration (SSC)] are generally the determinant of quality (Bianco and Pratt, 1977; Yamaguchi et al., 1977). However, SSC in five muskmelon cultivars were only partially correlated with sweetness (Mutton et al., 1981; Yamaguchi et al., 1977) and high SSC alone did not

\footnotetext{
Received for publication 4 Oct. 2006. Accepted for publication 14 June 2007. The mention of firm names or trade products does not imply that they are endorsed or recommended by the U.S. Department of Agriculture over other firms or similar products not mentioned.

We express sincere thanks to Dean Liere and Alex May, Syngenta Seeds, Inc., ROGERS Brand Vegetable Seeds, for managing, tagging, and supplying anthesis-tagged cantaloupe fruit. We also thank Gillian Eggelston for sugar analysis, and Amber D. Harts and James A. Miller for laboratory assistance. Statistical advice and support were obtained from Vicki Lancaster, Neptune and Company, Inc.

${ }^{1}$ Corresponding author. E-mail: beaulieu@srrc.ars.usda.gov.
}

appear to define good melon quality adequately (Aulenbach and Worthington, 1974; Currence and Larson, 1941; Mutton et al., 1981). Within a muskmelon fruit, markedly different sugar levels have been reported at different locations from stem to calyx across various tissue types (Mizuno et al., 1971). Accordingly, it is a challenge to present consistently the consumer with an optimum melon or fresh-cut muskmelon product with both postharvest keeping quality and optimized flavor.

Nevertheless, melons and fresh-cut melons are rapidly gaining popularity and a large share of the produce market across the United States (Bareuther, 2000). Total sales in the fresh-cut category (food service plus retail) was expected to be $\$ 14$ billion in 2005, and fresh-cut fruit sales are expected to top $\$ 1$ billion per year by 2008 (Produce Marketing Association, 2005). Retail scan data from Aug. 2002 to Aug. 2003 (performed by Information Resources, Chicago) indicated that fresh-cut fruit sales hit $\$ 243$ million, an impressive 15\% increase in 1 year (Western Farm Express, 2003). Sales trends for fresh-cut salads indicate clearly that consumers will pay for the convenience, if quality is perceived to be better than or equal to uncut product. However, fresh-cut fruit sales have lagged behind their counterpart, vegetables, because of numerous physiological and biochemical phenomena. Consumers often buy the first time based on appearance, but repeat purchases are driven by expected quality factors such as flavor and texture (Beaulieu, 2006; Waldron et al., 2003).

Cutting plant tissue increases respiration rates and woundinduced ethylene production, and causes major tissue disruption 
as sequestered enzymes and substrates become mixed (Toivonen and DeEll, 2002; Watada and Qi, 1999; Wiley, 1994). Minimal processing also increases the surface area per unit volume, which accelerates water loss. Altered water activity and mixing of intracellular and intercellular enzymes with substrates contributes to physiological, textural, and flavor changes/losses during or after cutting, which shortens storage life. These physiological changes may be accompanied by flavor loss, browning, decay, increased rate of vitamin loss, rapid softening, color loss, and a shorter storage life.

Maintaining flavor, aroma, postharvest, and microbial quality after processing and throughout the distribution chain is a major challenge facing the industry delivering fresh-cut fruit products. Processors believe that many fresh-cut fruit have about a 7- to 9-d postcutting life. Yet, to move from regional retail-based operations to centralized national manufacturing, a minimum shelf life of 7 to $14 \mathrm{~d}$ would be required. This has been achieved with many fresh-cut vegetables and salads, but not for most fresh-cut fruit because of numerous physiological reasons (Beaulieu and Gorny, 2004; Toivonen and DeEll, 2002; Watada and Qi, 1999; Watada et al., 1990; Wiley, 1994). We have demonstrated previously that muskmelon fruit harvested at different maturity deliver stored cubes differing significantly in flavor and textural attributes (Beaulieu et al., 2004). Subsequently, muskmelon fruit were evaluated during development and as fresh-cut cubes stored after preparation from various harvested maturities to assess physiological and quality changes during storage. The ultimate goal was to identify the best harvest maturity required to deliver fresh-cut muskmelon, with optimized physiological qualities, through storage.

\section{Materials and Methods}

Plant material. Orange-flesh muskmelons ('Sol Real') were grown in Kettleman City, CA (year 1), and Five Points, CA (year 2), as previously described (Beaulieu, 2006). Briefly, 4000 to 6000 flowers were tagged during anthesis in one morning during peak flowering, and developing fruit proximal to tagged flowers were removed. Developing fruit were harvested weekly for 4 weeks at 13, 20, 28, and $35 \mathrm{~d}$ after anthesis (DAA) in June/July (year 1) and 13, 20, 27, and 34 DAA in July in year 2. Fruit were field hydrocooled in an ice slurry, chilled $\left(\approx 5^{\circ} \mathrm{C}\right)$ until packed with Styrofoam beads, and shipped overnight to the Southern Regional Research Center, New Orleans (SRRC). For each sampling day, five immature developing fruit were used for analysis in year 1 whereas, six fruit were used in year 2. Data illustrating attributes in immature fruit were combined and graphed as 13, 20, 28, 35, and 38 DAA (corresponding with 3/4-slip at "typical commercial harvest"). Mature fruit were harvested in year 1 at 38 DAA with five distinct maturities: 1/4-, 1/2-, 3/4-slip, full-slip (FS), and overripe (OR); and in year 2 at 37 DAA, omitting OR. Onequarter slip fruit had a clearly green, well-attached peduncle, whereas 1/2-slip fruit had a distinct abscission layer detectable at the peduncle, roughly halfway in the stem. Three-quarter slip fruit (typical commercial harvest) were almost abscised at the peduncle, and FS fruit had just separated naturally, or was cleanly separated from the vine with light pressure. Numerous tagged fruit were flagged at FS, and OR was precisely categorized as $2 \mathrm{~d}$ past FS. Fruit were field hydrocooled, stored $2 \mathrm{~d}$ at $\approx 5^{\circ} \mathrm{C}$, packaged as noted, and freighted to the SRRC for analysis. In year 1, $5 \mathrm{~d}$ elapsed between harvesting and fresh cutting, and $4 \mathrm{~d}$ elapsed before cutting in year 2 .

Fresh-cut CUbe preparation. Fruit in optimum condition were washed in cold running tap water, sanitized in $100 \mu \mathrm{L} \cdot \mathrm{L}^{-1}$ $\mathrm{NaClO}(\mathrm{pH}, \approx 6.7)$, rinsed in deionized water, and uniformly peeled using a CP-44 Melon Peeler (Muro Co., Tokyo), except 13-DAA fruit, which were hand peeled with a carrot peeler. About 2 to $3 \times 2.5-\mathrm{cm}$ cubes were prepared in pielike wedges cut from the 2.5-cm-wide slices (Beaulieu and Lea, 2003). Equatorial tissue was preferred and were used over blossom and stemend cubes because curvature at the end of fruit lends to odd and misshapen cubes; however, stem and blossom end tissue were not precluded when cube size was sufficient. Processing was done under strict sanitary conditions, using good manufacturing practices in a food preparation kitchen. Cubes from numerous fruit (10 per maturity), were randomized, and roughly $300 \mathrm{~g}$ were randomly placed into 710-mL low-profile Juice Catcher containers (SRW-24-JC; Pactiv Corp. Lake Forest, IL). Freshcut cubes were stored at $4{ }^{\circ} \mathrm{C}$ and cubes were assessed from individual containers after $0,2,5,7,9,12$, and $14 \mathrm{~d}$ of storage.

SubJECTIVE APPRAISAL. A complete and uniform subjective quality criterion was established for fresh-cut muskmelon to help predict or point out overall quality deterioration (Beaulieu, 2005). Overall color, edge or tissue damage, spoilage, aroma/ smell, and desiccation were evaluated on a 1 to 9-point scale where 9 points = excellent (just cut, typical of the cultivar); 7 points = very good; 5 points $=$ good, limit for marketing; 3 points $=$ fair, absolute limit for household use with trimming or loss; and 1 point $=$ poor, inedible. Odd whole numbers were sound judgments whereas even numbers were used for borderline decisions. Three trained judges independently performed subjective assessments each sampling day and their results were averaged.

Physiological measurements. Percent SSC was measured from extracted juice samples or expressed cubes with a handheld electronic refractometer (PR101; Atago, Tokyo). Firmness was measured instrumentally (Stable Micro System Texture Analyzer TA.XT2; Texture Technologies, Scarsdale, NY) as described previously (Beaulieu et al., 2004). Briefly, 10 freshcut cubes, per maturity, were selected and carefully trimmed on each side to $1 \mathrm{~cm}$ with two razor blades mounted in a stainless steel device. A compression test was performed in perfect 1$\mathrm{cm}^{3}$ cubes using a 4-cm-diameter flat compression probe $(100 \mathrm{~g}$ force, $0.981 \mathrm{~N}$ ) with a force to $75 \%$ of original size. Firmness was also measured in individual cubes with a hand-held penetrometer (FT327; McCormick, Alphonsine, Italy) using an $8-\mathrm{mm}$ probe. Cubes were manually held in position while the probe was rapidly inserted, perpendicularly to the surface, until the demarcation on the probe. With immature fruit, percent SSC was sampled in triplicate from 15 fruit (year 1) and 18 fruit (year 2), with five fresh-cut cubes per triplicate container [experimental unit (EU)] per treatment each year. Color $\left(\mathrm{L}^{*}\right.$, $\mathrm{a}^{*}$, and $\mathrm{b}^{*}$ ) was recorded with a Hunter color meter (DP-9000; Hunter Associates Laboratory, Reston, VA) calibrated against both white $\left(93.088,-0.689\right.$, and -0.099 , for $L^{*}, a^{*}$, and $b^{*}$ respectively) and black color tiles. Four color measurements were taken per cube from immature fruit ( 15 in year 1 and 18 in year $2 ; n=132$ ) and from five fresh-cut cubes per triplicate EU, per treatment combination $(n=120)$. All penetrometer and color readings were taken from the sides of each cube that were sliced with a sharp knife, not the soft internal cavity side or the external side peeled by the Muro peeler. 
Total vitamin C analysis. A high-performance liquid chromatography (HPLC) method developed for simultaneous measurement of ascorbic acid (AA) and dehydroascorbic acid (DHA) was used (Zapata and Dufour, 1992), with modification. Because researchers and some companies producing fresh-cut fruit often use isoascorbic acid and isomers as antibrowning agents, kojic acid (KA) replaced isoascorbic acid as the internal standard. Cubes were homogenized with the Braun MP80 food processor (Gillette Co., Boston), slurry was sieved through two layers of Miracloth (Cedarlane Laboratories Ltd, Hornby, ON, Canada), $1 \mathrm{~mL}$ was placed into a $10-\mathrm{mL}$ volumetric flask to which $1 \mathrm{~mL}$ KA solution (internal standard) was added, and 140 $\mu \mathrm{L}$ of a $1.0 \mathrm{~N} \mathrm{HCl}$ solution was added to acidify the reaction. Then $5 \mathrm{MeOH}: 95 \mathrm{MilliQ}$ water (v/v) was added up to $10 \mathrm{~mL}$, mixed thoroughly, transferred to a centrifuge tube covered tightly with parafilm (Pechiney Plastic Packaging Co., Chicago), and centrifuged (Sorvall RC 5B Superspeed Centrifuge; DuPont Instruments, Wilmington, DE) $5 \mathrm{~min}$ at $10,000 g_{\mathrm{n}}$ at $4{ }^{\circ} \mathrm{C}$. Supernatant ( $\left.3 \mathrm{~mL}\right)$ was removed to a test tube, to which $1 \mathrm{~mL}$ derivatizing solution, 1,2-benzenediamine dihydrochloride, was added (final $\mathrm{Ph}, 2.20-2.45$ ), vortexed for $5 \mathrm{~s}$, filtered through a $45-\mu \mathrm{m}$ filter disk syringe into a brown sample vial, crimp sealed with a septa-lid, placed $37 \mathrm{~min}$ in total darkness at room temperature $\left(\approx 20{ }^{\circ} \mathrm{C}\right)$, then read on the HPL chromatograph. A Hewlett Packard 1090 Series II HPLC (Agilent Technologies, Santa Clara, CA) was equipped with an Alltima C18 (Alltech Assoc., Deerfield, IL) precolumn $(3 \times 4.6 \mathrm{~mm})$ and an Alltima C18 column $(250 \times 4.6 \mathrm{~mm})$, with a variable wavelength ultraviolet detector and an automatic $(20 \mu \mathrm{L})$ sampling loop. The mobile phase was HPLC-grade 5 methanol : 95 water $(\mathrm{v} / \mathrm{v})$ containing $5 \mathrm{~mm}$ cetrimide (hexadecyltrimethylammonium bromide) and $50 \mathrm{mM} \mathrm{KH}_{2} \mathrm{PO}_{4}$ with a $1.8-\mathrm{mL} \cdot \mathrm{min}^{-1}$ flow rate with 12-min runs. 1,2-Benzenediamine dihydrochloride derivatizes DHA into the fluorophore 3-(1,2-dihydroxyethyl)furo[3,4-b]quinoxaline-1-one at $348 \mathrm{~nm}$, and AA and KA were then detected at $261 \mathrm{~nm}$. Concentrations were determined based on internal standard (KA) in all samples and known standard calibration curves of AA $\left(r^{2}=0.999\right)$ and DHA $\left(r^{2}=0.999\right)$. Analysis was performed in triplicate only in year 1 .

Sugar analysis. Sucrose, glucose, and fructose were analyzed by gas chromatograph (GC) on a Hewlett Packard 5890A (Agilent Technologies) equipped with a flame ionization detector, based on the International Commission for Uniform Methods of Sugar Analysis method GS7/3-22 (2002), with modifications (Beaulieu et al., 2003; Eggleston et al., 2002). A DB-5 capillary column (5\% phenyl-methyl polysiloxane, $30 \mathrm{~m}, 0.25-\mathrm{mm}$ internal diameter, with a column film thickness of $0.1 \mu \mathrm{m})$, was used with the following GC conditions: injection port, $300{ }^{\circ} \mathrm{C}$; detector $310,{ }^{\circ} \mathrm{C}$, oven started at 100 ${ }^{\circ} \mathrm{C}$ for $3 \mathrm{~min}$ then was programmed at $5 \%$ min until $150{ }^{\circ} \mathrm{C}$, then $10 \%$ min until $300{ }^{\circ} \mathrm{C}$, remaining at $300{ }^{\circ} \mathrm{C}$ for $10 \mathrm{~min}$. Head pressure was $145 \mathrm{kPa}$ with a $25: 1$ split ratio; sample volume was $1 \mu \mathrm{L}$. Trehalose dihydrate (Alltech Assoc.) was the internal standard for sucrose, and methyl-a-D-glucopyranoside (SigmaAldrich, St. Louis) was the internal standard for glucose and fructose. Analysis was only performed in year 1 on immature fruit. Data were expressed as the percent sugar in juice basis (w/ w), where percent SSC was measured in samples with a temperature-controlled refractometer accurate to $\pm 0.01 \%$ (TCR 15-30; Index Instruments, Ramsey, UK).

Statistical analysis. Data were analyzed using SAS Proc Mixed (SPlus release 8.2; SAS Institute, Cary, NC). For harvest maturity and storage as fresh-cut cubes, data were analyzed as a randomized complete block design with a two-way treatment structure $(7 \times 5)$ with seven storage levels (days $0,2,5,7,9,12$, and 14) and five maturity levels (1/4-slip, 1/2-slip, 3/4-slip, FS, and OR), with the exception of color and the subjective variable edge or tissue damage. The study was repeated in 2 years; however, there were no year 1 measurements for days 12 and 14 , and there were only measures for OR in year 1. Each treatment combination had three discrete containers as replications (EU), from which individual cubes comprised subsamples. The Tukey multiple comparison procedure was used to evaluate mean differences when main effect or interaction means were statistically significant $(P<0.05)$. All multiple comparisons (e.g., intercepts and slopes with 95\% confidence intervals) were conducted at the 0.05 level of significance. With regard to the $\mathrm{L}^{*}, \mathrm{a}^{*}$, and $\mathrm{b}^{*}$ color data, measurements in year 2 for day 7 were dropped from the analyses because of anomalous readings that could not be resolved. The initial fresh-cut cube color analyses showed a significant year effect $(P<0.0001)$. Subsequently, to eliminate the possibility that interaction effects were a result of the missing treatment combination within years, only those day and maturity levels that were measured in both years were analyzed together. Color data were analyzed as a randomized complete block design with a two-way treatment structure $(4 \times 4)$ with four storage levels (days 0, 2, 5, and 9) and four maturity levels (1/4-slip, 1/2-slip, 3/4-slip, FS). The data for the subjective evaluation of edge or tissue damage were not normal, so a nonparametric test (Kruskal-Wallace rank sum) for main effect differences was conducted and a nonparametric test for trend (Mann-Kendall), was applied. The Mann-Kendall test for trends was also applied to the vitamin $\mathrm{C}$ data analysis.

\section{Results and Discussion}

Previous studies have shown there are significant differences between volatiles in immature fruit that were harvested during growth and development versus mature fruit harvested during late stages of growth and development (Beaulieu, 2006; Beaulieu and Grimm, 2001; Shalit et al., 2001). Correspondingly, one would expect significant physiological changes between immature and mature fruit, as previously described (Lester, 1990, 1998; Lester and Dunlap, 1985; Pratt, 1971; Pratt et al., 1977; Wyllie et al., 1996). This was reconfirmed and extended for stored fresh-cut cubes via analysis of color, firmness, sugars, and vitamin $\mathrm{C}$ in 'Sol Real' muskmelon.

\section{Physiological trends: Immature to mature fruit}

The Hunter $\mathrm{L}^{*}$ and $\mathrm{a}^{*}$ values indicated a marked color change from pale green to light orange that occurred 28 DAA (Fig. 1). The $\mathrm{a}^{*}$ value changed sharply from negative (greenness) to positive (redness) and, concomitantly, the $\mathrm{L}^{*}$ value (lightness) decreased, indicating a change from lighter to darker orange. The seed cavities were fully mature by 35 DAA and the tissue was already light orange with a faintly characteristic muskmelon odor. There was, furthermore, a marked distinction between 35 DAA versus 38 DAA in terms of ester and acetate concentration (Beaulieu, 2006). There was also a gradual then marked decrease in firmness as well as an increase in percent SSC during fruit development to harvest on 37 and 38 DAA (Fig. 2). From 13 DAA until harvest there was a total 51.9\% decrease in firmness, yet roughly one-third of the overall 


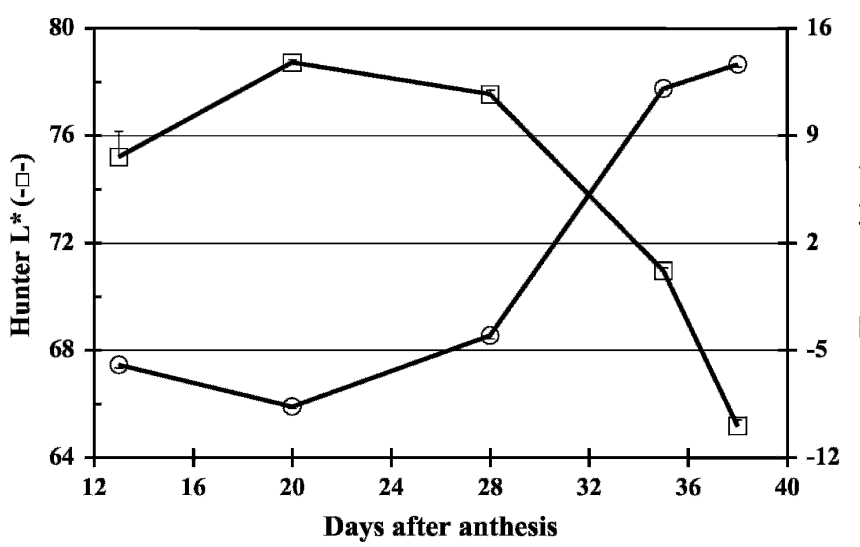

Fig. 1. Hunter L* and a* color change during fruit development in 'Sol Real' muskmelon mesocarp tissue. Data are combined over 2 years; $n=132 \pm$ SE. Most error bars are hidden by the data points.

firmness loss $(32.5 \%)$ occurred only during $3 \mathrm{~d}$ : from 34 to 35 DAA to 37 to 38 DAA. During growth and development through to commercial harvest, SSC doubled $(5.37 \%$ to $10.62 \%)$.

Percent glucose and fructose in the juice were highly correlated ( $r=0.997, P=0.002)$, and remained somewhat stable during development, each comprising roughly $2 \%$ sugar in juice (w/w) of the total sugars (Fig. 3). Twenty-eight DAA, sucrose markedly increased, and this was positively correlated with increases in both total sugars $(r=0.882, P=0.084)$ and percent SSC $(r=0.939, P=0.041)$ of the expressed samples. Sucrose concentration was correlated to total sugar concentration in numerous $C$. melo cultivars that accumulate sucrose (Stepansky et al., 1999). As previously noted in muskmelons (Hubbard et al., 1989; Lester et al., 2001; McCollum et al., 1988; Wang et al., 1996), there was almost no sucrose accumulation during the early stages of growth and development as the glucose and fructose concentrations increased slightly through 28 DAA. It has been well established that sucrose accumulates massively during the final stages of maturation and is the dominant sugar in most dessert melons (Bianco and Pratt, 1977; Hubbard et al., 1989; Lester, 1998; Lester and Dunlap, 1985; Lester et al., 2001; McCollum et al., 1988; Stepansky et al., 1999; Wang et al., 1996). During devel-

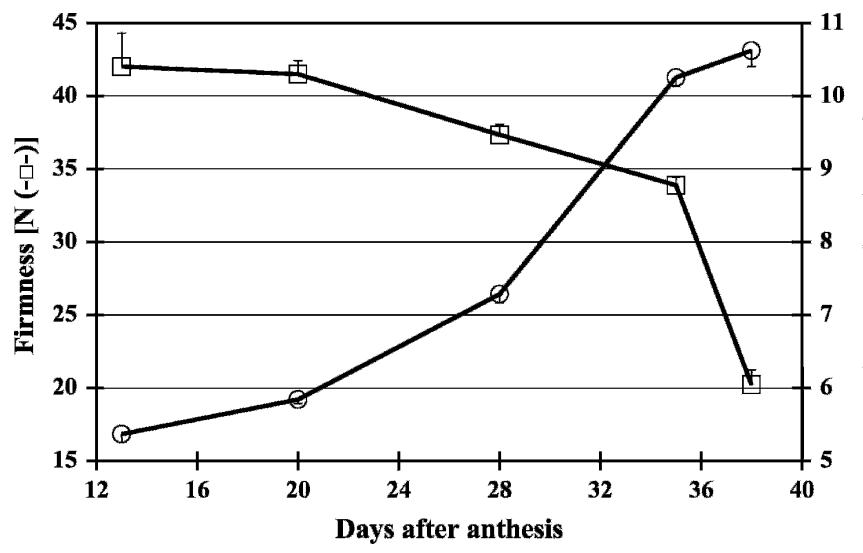

Fig. 2. Firmness and percent soluble solids change during fruit development in 'Sol Real' muskmelon mesocarp tissue. Data are combined over 2 years; $\mathrm{n}=93 \pm$ SE. Most error bars are hidden by the data points.

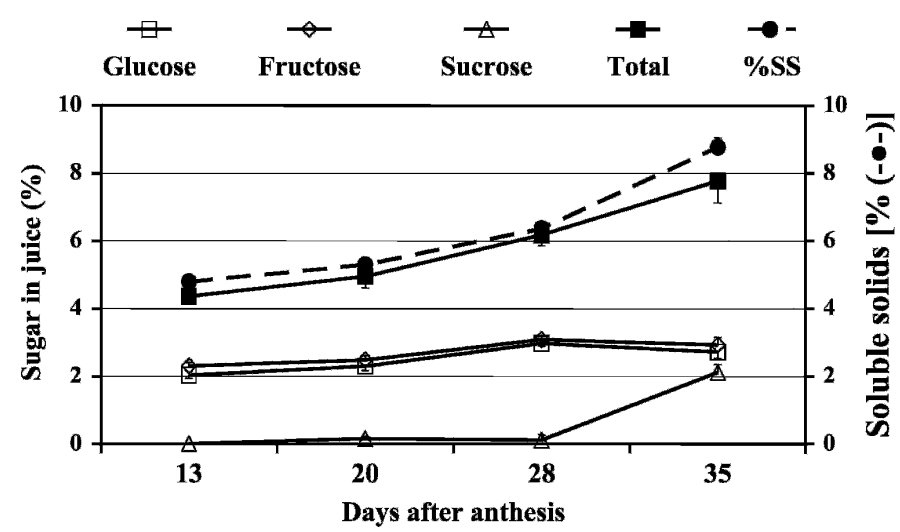

Fig. 3. Sugars (sucrose, glucose, and fructose) and percent soluble solids (SS) in 'Sol Real' muskmelon mesocarp tissue during fruit development. Single year data (year 1$) ; n=3 \pm$ SD per point.

opment, total sugars and percent SSC were highly positively correlated ( $r=0.990, P=0.007)$, as illustrated in Fig. 3 . We previously documented that percent SSC in expressed cubes and homogenized juice were correlated, and that cube measures were generally higher (Beaulieu et al., 2003). The current data again illustrate how expressed percent SSC readings slightly overestimate (1\% to $2 \%)$ true sugar content of the tissue.

Vitamin C (combined DHA and AA) had a statistically significant increasing trend (Mann-Kendall test for trend, $P=$ 0.042 ) during development from 12 through 35 DAA (Fig. 4). The individual components of total vitamin $\mathrm{C}$ (AA and DHA) followed the same general trend (data not shown). Vitamin $\mathrm{C}$ peaked at 35 DAA $(47.3 \mathrm{mg} / 100 \mathrm{~g})$, and afterward there was a decrease in vitamin $\mathrm{C}$ content between 35 DAA and the beginning of cutting. This loss, independent of maturity, was likely the result of shipping, handling, and the natural senescence process. Nonetheless, upon processing, all four maturities contained between 33.8 to $40.9 \mathrm{mg} / 100 \mathrm{~g}$ vitamin $\mathrm{C}$, which falls within the range of $36.7 \mathrm{mg} / 100 \mathrm{~g}$ reported in the U.S. Department of Agriculture (USDA) National Nutrient Database for Standard Reference (U.S. Department of Agriculture, 2006).

The $\mathrm{pH}$ of the mesocarp tissue (homogenized) dropped to the lowest value (5.25) 27 to 28 DAA, just before physiological maturity (the point at which viable seed achieves its maximum

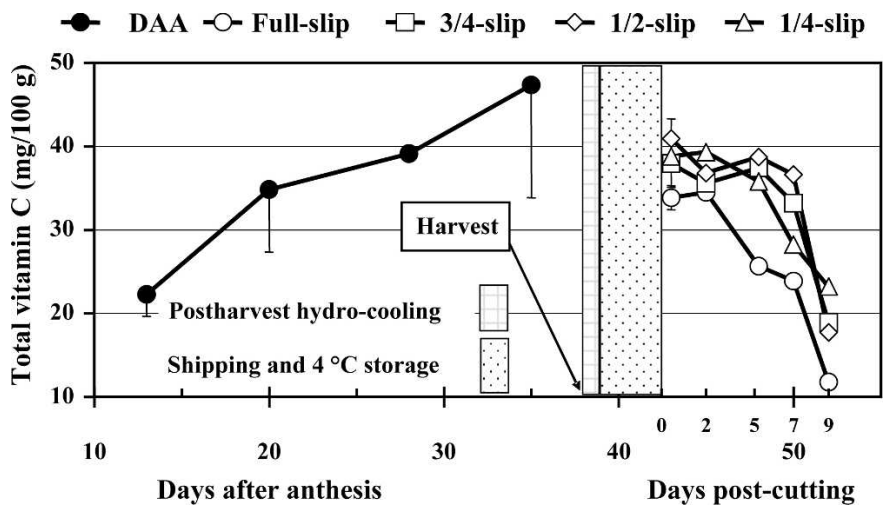

Fig. 4. Total vitamin C (ascorbic acid + dehydroascorbic acid) in 'Sol Real' muskmelon mesocarp tissue during fruit development. Single year data (year $1) ; n=3 \pm$ sD per point. DAA, days after anthesis. 
dry weight), then increased markedly during growth and development, peaking (6.51-6.79) after harvest (Fig. 5) as previously reported (Wang et al., 1996).

\section{Physiological trends: Stored fresh-cut cubes prepared at various maturities}

There were numerous significant main effect or interaction means, and clearly significant maturity-dependent trends for various physiological parameters in stored fresh-cut muskmelon prepared from fruit harvested at distinctly different maturities. In general, the fresh-cut cubes maintained very good appearance throughout the duration of storage (14 d) while held under ideal conditions at optimal temperatures $\left(4^{\circ} \mathrm{C}\right)$.

Subjective Quality assessment. Consumers might not notice subtle quality deterioration of fresh-cut fruit in the package, and we have determined that discrete quality evaluations by trained persons can often highlight physiological deterioration earlier than apparent overall quality loss deems the product commercially unacceptable (Beaulieu et al., 2003). A similar trend was again observed in fresh-cut muskmelon, using a rigorous subjective quality criterion (Beaulieu, 2005), even though product remained acceptable and marketable (averaged scores, $\geq 5$ points) throughout storage. Herein, overall fresh-cut muskmelon held with good appearance through the duration of storage (up to $14 \mathrm{~d}$ ) with little exception. Edge and tissue damage declined significantly after $5 \mathrm{~d}$ in storage, and there was a significant mean separation between days 0 to 5 versus 7 to 14 (Table 1). It is noteworthy to mention that these results indicating acceptable appearance occur in a product that has not withstood the rigors of normal commercial shipping and handling. A nonparametric Kruskal-Wallace rank sum test for main effect differences in edge or tissue damage was conducted, and there were statistically significant year and day main effects (Table 1). There was also a statistically significant downward trend with increasing storage time using the nonparametric test for trend (Mann-Kendall; test statistic = $-18, P=0.0014)$. The same general trend was observed in the overall averaged subjective data for all treatments, which was driven most by the single parameter "desiccation" (data not shown). Gradual deterioration is an expected result of general senescence, and little to no microbial decay (data not shown) was indicated because no precipitous "spoilage" or subjective

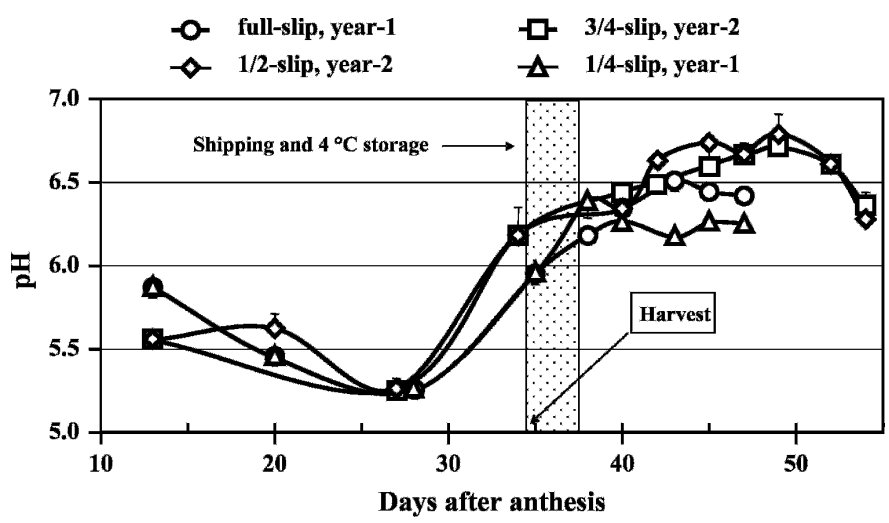

Fig. 5. The pH of homogenized mesocarp tissue in 'Sol Real' muskmelon during fruit development and fresh-cut cube storage. Mixed-year data; $n=3 \pm$ sD per point. Fresh-cut days are not specified because of slight temporal differences between years from harvest to cutting.
Table 1. Analysis of variance for subjective "edge and tissue damage," with a Kruskal-Wallace multiple comparison procedure (experiment wise error rate $=0.05$ ) to determine mean separation, in fresh-cut muskmelon prepared at various maturity and stored up to $14 \mathrm{~d}$ at $4{ }^{\circ} \mathrm{C}$.

\begin{tabular}{lccc}
\hline Source of variation & $\mathrm{df}$ & $\chi^{2}$ & $P$ \\
\hline Year & 1 & 35.483 & 0.0000 \\
Day & 6 & 54.079 & 0.0000 \\
Maturity & 4 & 3.742 & 0.4421 \\
Day & $\mathrm{n}$ & Mean & Mean separation \\
0 & 27 & 8.70 & $\mathrm{a}$ \\
2 & 27 & 8.18 & $\mathrm{~b}$ \\
5 & 27 & 8.11 & $\mathrm{~b}$ \\
7 & 27 & 7.00 & $\mathrm{de}$ \\
9 & 27 & 7.22 & $\mathrm{c}$ \\
12 & 15 & 7.00 & $\mathrm{de}$ \\
14 & 15 & 6.86 & $\mathrm{e}$
\end{tabular}

${ }^{\mathrm{z}}$ Means followed by the same lowercase letter were not significantly different $(P>0.05)$ from each other.

average declines were observed. Based on overall average subjective scores through the whole experiment, only one treatment, 1/2-slip day 14 , had possible microbial deterioration or more rapid decay (5.8) compared with the other day 14 treatments (7.0). This treatment (1/2-slip day 14) also had the only incidence of a subjective "spoilage" score attaining the cutoff (5 points) for marketability. There were significant day $(P<0.0001)$ and day $\times$ maturity $(P<0.0001)$ effects for both aroma/smell and desiccation. No significantly different maturity main effects for these parameters indicates that gradual deterioration occurred during storage, which was independent of maturity. This was evidenced by statistically significant day $\times$ maturity interaction effects in "aroma/smell" and "desiccation."

Color (Hunter). Because the initial instrumental color analyses showed a significant year effect $(P<0.0001)$, only those days $(0,2,5$, and 9$)$ and maturity levels measured in both years were analyzed. The Hunter tristimulus color measurements $\mathrm{L}^{*}, \mathrm{a}^{*}$, and $\mathrm{b}^{*}$ had statistically significant $(P<0.005)$ year, day, and maturity effects, and no statistically significant $(P>0.109)$ day $\times$ maturity interaction effects (Table 2$)$. This was corroborated with statistically significant year, day, and day $\times$ maturity interaction effects in subjective color appraisals (data not shown). For each color measurement, $\mathrm{L}^{*}$, $\mathrm{a}^{*}$, and $\mathrm{b}^{*}$, day 9 had the smallest mean value that was statistically different $(P=0.05)$ from day 0 , the largest mean value (Table $3)$. There were no mean trends for maturity in $\mathrm{L}^{*}$ and $\mathrm{a}^{*}$ color measurements, and color at harvest was 66.06 and 13.63 for $\mathrm{L}^{*}$ and $\mathrm{a}^{*}$ respectively. There was an increasing mean trend for $\mathrm{b}^{*}$; as maturity increased, so did the mean value of $b^{*}$. Overall, tissue became lighter $\left(\mathrm{L}^{*}\right)$, less red-orange $\left(\mathrm{a}^{*}\right)$, and more yellowish $\left(b^{*}\right)$. However, as previously reported (Boynton et al., 2005), there were not consistent changes in hue during storage (data not shown). Cantaloupe has weak polyphenol oxidase activity, which helps explain the lack of browning reactions in the cut product, even though water-dipped cubes have demonstrated significantly different color (chroma and L*) compared with cut control cubes (Lamikanra et al., 2000).

FiRMNESS (HAND HELD AND INSTRUMENTAL). There was no statistically significant year effect for hand-held (McCormick) firmness in stored fresh-cut cubes. There were statistically 
Table 2. Analysis of variance and parameter estimates for Hunter color measurements $\left(\mathrm{L}^{*}, \mathrm{a}^{*}\right.$, and $\left.\mathrm{b}^{*}\right)$ in fresh-cut cantaloupe stored at $4{ }^{\circ} \mathrm{C}$.

\begin{tabular}{|c|c|c|c|c|c|}
\hline Source of variation & $\mathrm{df}$ & Sum of squares & Mean square & $\mathrm{F}$ & $P$ \\
\hline \multicolumn{6}{|l|}{ Hunter L* } \\
\hline Day & 3 & 17.860 & 5.953 & 4.578 & 0.0052 \\
\hline Day $\times$ maturity & 9 & 17.780 & 1.642 & 1.263 & 0.2704 \\
\hline Residual & 79 & 102.736 & 1.300 & & \\
\hline \multicolumn{6}{|l|}{ Hunter a* } \\
\hline Maturity & 3 & 7.033 & 2.344 & 4.800 & 0.0040 \\
\hline Day $\times$ maturity & 9 & 3.047 & 0.339 & 0.693 & 0.7131 \\
\hline Residual & 79 & 38.589 & 0.488 & & \\
\hline \multicolumn{6}{|l|}{ Hunter b* } \\
\hline Year & 1 & 127.846 & 127.846 & 219.446 & $<0.0000$ \\
\hline
\end{tabular}

Color data were analyzed as a randomized complete block design with a two-way treatment structure $(4 \times 4)$ with four storage levels $($ days 0 , 2, 5, and 9) and four maturity levels (1/4-slip, 1/2-slip, 3/4-slip, full-slip).

significant day $(P<0.0001)$ and maturity $(P<0.0001)$ main effects and day $\times$ maturity $(P=0.006)$ interaction effects (Table 4$)$. There was a negative linear trend over the length of storage for each maturity level; the slopes decreased with increasing maturity (Table 4). This indicates that the effect of storage duration decreased as maturity increased, and this was reflected in the slope estimates. The intercept for 1/4-slip was statistically different from the four other maturity levels, indicating that day 0 firmness in 1/4-slip cubes was statistically different from the other four maturity levels, similar to instrumentally observed texture (Beaulieu et al., 2004). Use of a texture analyzer has illustrated consistent firmness loss in stored fresh-cut muskmelon with both a puncture test (Gil et al., 2006; Luna-Guzmán and Barrett, 2000) and a compression test (Beaulieu et al., 2004).

The modulus of elasticity (Young's modulus), the ratio of stress to strain as calculated from the slope of the force/ deformation curve before the elastic limit (at the first bioyield), is correlated with firmness (Abbott and Harker, 2004). Young's

Table 3. Mean estimates for Hunter $\mathrm{L}^{*}$, $\mathrm{a}^{*}$ and $\mathrm{b}^{*}$ color in stored $\left(4^{\circ} \mathrm{C}\right)$ fresh-cut muskmelon, prepared at various maturity, according to Tukey multiple comparison procedure with an experiment wise error rate $=0.05$.

\begin{tabular}{llcc}
\hline & \multicolumn{3}{c}{ Multiple mean comparisons } \\
\cline { 2 - 4 } Days & \multicolumn{1}{c}{$\mathrm{L}^{*}$} & $\mathrm{a}^{*}$ & $\mathrm{~b}^{*}$ \\
\hline 0 & $66.06 \mathrm{a}^{\mathrm{z}}$ & $13.63 \mathrm{a}$ & $40.09 \mathrm{a}$ \\
2 & $65.72 \mathrm{ab}$ & $13.63 \mathrm{a}$ & $40.15 \mathrm{a}$ \\
5 & $65.94 \mathrm{a}$ & $13.10 \mathrm{ab}$ & $39.89 \mathrm{a}$ \\
9 & $65.01 \mathrm{~b}$ & $12.74 \mathrm{~b}$ & $39.24 \mathrm{~b}$ \\
Maturity & & & \\
$\quad$ 1/4-slip & $66.67 \mathrm{~b}$ & $12.82 \mathrm{~b}$ & $39.13 \mathrm{~b}$ \\
1/2-slip & $65.10 \mathrm{a}$ & $13.48 \mathrm{a}$ & $39.74 \mathrm{a}$ \\
3/4-slip & $65.05 \mathrm{a}$ & $13.49 \mathrm{a}$ & $40.19 \mathrm{a}$ \\
Full-slip & $65.98 \mathrm{~b}$ & $13.31 \mathrm{ba}$ & $40.30 \mathrm{a}$ \\
& & &
\end{tabular}

${ }^{\mathrm{z}}$ Day and maturity means, per column, followed by the same lowercase letter were not significantly different $(P>0.05)$ from each other. modulus followed a decreasing linear trend that was maturity dependent (Fig. 6). Again, the magnitude of the slope decreased with maturity $(1 / 4 \mathrm{slip}=-1.805$ to $\mathrm{FS}=-0.033)$, an indication that the effect of storage time decreased as maturity increased. This was demonstrated in the slope estimates for FS, which were not statistically different from $0(P=0.842)$. The Young's modulus mean for 1/4-slip versus 1/2-slip, 3/4-slip, and FS was statistically different $(P=0.05)$ on day 0 , but by day 7 the four maturity means were not statistically different $(P=0.05)$. On day 0 , the Young's modulus mean for $1 / 4$-slip was significantly suppressed as a result of significantly longer times required to attain the distance to bioyield (data not shown). We previously reported that Young's modulus had a significant negative correlation with wetness, and positive correlation with hardness and cohesiveness (Beaulieu et al., 2004). Subsequently, preparing fresh-cut cubes with FS fruit results in a "wet" product that has poor hardness.

Whole muskmelon fruit and cube firmness was also positively correlated with increasing acetate ester levels (Beaulieu, 2005), and acetate loss was correlated with firmness loss in stored fresh-cut cubes (Beaulieu, 2006). To deliver a longer shelf life, some companies producing fresh-cut products prefer to process less-mature fruit, which are typically firmer, as clearly demonstrated within this study. However cubes prepared with less-mature fruit that are excessively firm, lack flavor volatiles (Beaulieu, 2006) and have inferior, less acceptable sensory attributes (Beaulieu et al., 2004).

Percent soluble solids concentration. There were statistically significant main effects for year $(P<0.0001)$, day $(P<0.0001)$, and maturity $(P=0.002)$, and the year mean effect for percent SSC was substantial. We previously illustrated that percent SSC declined markedly in all four maturities after $7 \mathrm{~d}$ of storage, and SSC was much lower in 1/4-slip cubes compared with the other three harvest maturities through $9 \mathrm{~d}$ of storage (Beaulieu and Baldwin, 2002). However, trends in the combined 2-year data set were not as apparent because the overall percent SSC levels were higher in year 2 (data not shown). There was an increasing trend in percent SSC for maturity from 
Table 4. Parameter estimates for hand-held firmness (8-mm probe; McCormick, Alphonsine, Italy) in fresh-cut muskmelon stored at $4{ }^{\circ} \mathrm{C}$.

\begin{tabular}{|c|c|c|c|c|c|c|c|c|}
\hline \multirow[b]{2}{*}{ Maturity } & \multicolumn{4}{|c|}{ Intercept } & \multicolumn{4}{|c|}{ Slope } \\
\hline & $95 \% \mathrm{LCL}^{\mathrm{z}}$ & Mean & Sig. ${ }^{y}$ & $95 \% \mathrm{UCL}^{\mathrm{z}}$ & $95 \%$ LCL & Mean & Sig. & $95 \% \mathrm{UCL}$ \\
\hline 1/4-slip & 19.707 & 21.070 & $\mathrm{a}$ & 22.434 & -0.973 & -0.789 & $\mathrm{a}$ & -0.604 \\
\hline 1/2-slip & 16.039 & 17.402 & $\mathrm{~b}$ & 18.766 & -0.820 & -0.636 & $a b$ & -0.452 \\
\hline Full-slip & 15.871 & 17.234 & $\mathrm{~b}$ & 18.598 & -0.611 & -0.427 & $a b$ & -0.243 \\
\hline Overripe & 14.494 & 16.365 & $\mathrm{~b}$ & 18.237 & -0.467 & -0.246 & $\mathrm{~b}$ & -0.024 \\
\hline
\end{tabular}

${ }^{\mathrm{z}} \mathrm{LCL}$, lower confidence limit; UCL, upper confidence limit with $95 \%$ confidence intervals.

${ }^{y}$ Sig., confidence interval significance of mean separation $(P<0.05)$. Means, per column, followed by the same lowercase letter were not significantly different from each other.

Data were analyzed as a randomized complete block design with a two-way treatment structure $(7 \times 5)$ with seven storage levels $($ days $0,2,5$, 7, 9, 12, and 14) and five maturity levels (1/4-slip, 1/2-slip, 3/4-slip, full-slip, and overripe).

1/4-slip to OR in the combined analysis, yet there did not appear to be significantly different trends during the length of storage (data not shown). This is not surprising considering that substantially different spatial distribution of sugars has been reported within individual melon fruit (Mizuno et al., 1971). In previous 1-year studies, decreases in percent SSC and sugar concentration were reported in numerous eastern and western shipper fresh-cut muskmelon cultivars (Beaulieu, 2005; Cantwell and Portela, 1997; Lange, 1998).

Vitamin C AND PH. Cubes prepared from all four harvest maturities had statistically significant decreasing trends (MannKendall test for trend, $P=0.042$ ) in vitamin $\mathrm{C}$ content that occurred at or just after $7 \mathrm{~d}$ in storage (corresponding with 50 DAA) at $4{ }^{\circ} \mathrm{C}$ (Fig. 4). Vitamin $\mathrm{C}$ losses were greater in freshcut cubes prepared from FS fruit $(65 \%)$ than less-mature fruit: 3/4-slip, 50\%; 1/2-slip, 48\%; and 1/4-slip, 40\%. This trend is logical in that more mature fruit will senescence faster (corroborated by the previous firmness data), and hence lose quality traits quicker than less mature fruit. Similar AA decreases have been reported during storage in whole fruit, and especially in more mature FS fruit (Evensen, 1983). Slight vitamin C losses in fresh-cut muskmelon were recently reported (Gil et al., 2006), although absolute levels of vitamin $C$ recovered were very low compared with our study and with the reference data in the USDA National Nutrient Database for Standard Reference (U.S. Department of Agriculture, 2006). Nonetheless, this is the first report of maturity-dependent vitamin C loss in freshcut fruit. Corresponding with decreasing vitamin $\mathrm{C}$ content, the

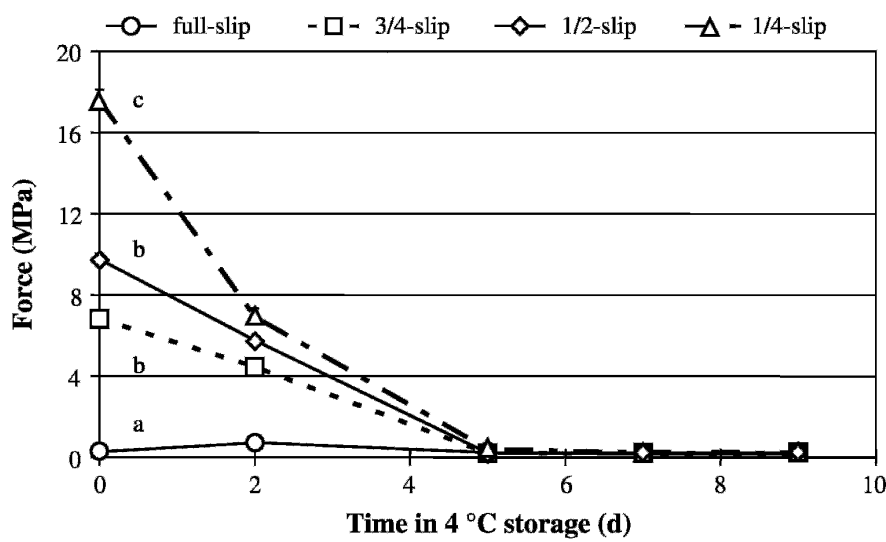

Fig. 6. Instrumental firmness (Young's modulus) in stored $\left(4{ }^{\circ} \mathrm{C}\right) 1-\mathrm{cm}^{3}$ freshcut muskmelon cubes prepared from fruit at four maturity levels (1/4-slip, 1/2-slip, 3/4-slip, and full-slip). Single-year data (year 1); sE, standard error bars about the means; $n=10$. Most error bars are hidden by the data points.
$\mathrm{pH}$ of cut tissue also decreased toward the end of storage. Only year effects were observed in $\mathrm{pH}$, and there were no significant differences between maturities. Subsequently, random maturity and year traces were presented (Fig. 5). A generally neutral pH was conserved during storage, and fruit were only acidic during immature stages. This cultivar (Sol Real) had marked $\mathrm{pH}$ fluctuation during growth and development compared with another orange flesh cultivar previously reported (Lester and Dunlap, 1985). The absence of marked acidity increase during storage as fresh-cut cubes indicates little lactic acid bacterial growth, as previously reported (Lamikanra et al., 2000).

\section{Conclusion}

During muskmelon development, Hunter a* values changed sharply from negative (greenness) to positive (redness), and $\mathrm{L}^{*}$ values decreased from light orange to dull, then deeper orange 27 to 28 DAA. Sucrose markedly increased 28 DAA, and this was positively correlated with increases in total sugars $(r=$ $0.882, P=0.084)$ and percent SSC $(r=0.939, P=0.041)$. Total vitamin $\mathrm{C}$ significantly increased $(P=0.042)$ during development from 12 through 35 DAA. The $\mathrm{pH}$ of the mesocarp tissue (homogenized) dropped to the lowest value (5.25) 27 to 28 DAA, just before physiological maturity, then increased markedly during development and maturity, peaking after harvest (6.51-6.79), and generally declined by the end of storage as fresh-cut cubes.

To the best of our knowledge, this study, including others (Beaulieu, 2006; Beaulieu et al., 2004), was the first to evaluate physiological, volatile, and sensory differences comprehensively in fresh-cut muskmelons prepared from several distinct initial maturity stages. In general, the fresh-cut cubes maintained a very good appearance throughout the duration of storage $(14 \mathrm{~d})$ while held at optimal temperatures $\left(4^{\circ} \mathrm{C}\right)$. Gradual subjective deterioration occurred during storage, which was independent of maturity, and there were statistically significant day and maturity main effects and day $\times$ maturity interaction effects. Vitamin C losses were greater in fresh-cut cubes prepared from FS fruit (65\%) compared with less-mature fruit: 3/4-slip, 50\%; 1/2-slip, 48\%; and 1/4-slip, 40\%. There was a negative linear trend over the length of storage in hand-held firmness for each maturity level, indicating that the effect of storage duration decreased as maturity increased.

Significant maturity-independent declines of firmness and acetate in fresh-cut cubes of 'Sol Real' have been observed, as reported herein and previously (Beaulieu, 2006; Beaulieu et al., 2004). Herein, and in another 2 -year repeated study with 'Sol 
Real' (Beaulieu, 2005), fresh-cut cubes rapidly lost firmness, and acetate levels concomitantly declined during storage. Coinciding with reduced volatiles recovered in 1/4-slip fruit (Beaulieu, 2006) was the fact that these fresh-cut cubes retained more firmness during storage compared with the other three maturities (Beaulieu et al., 2004). Parallelism may be drawn between our findings and those in sliced pear (Pyrus calleryana Decne 'Bradford') (Gorny et al., 1998a) and peach [Prunus persica (L.) Batsch] (Gorny et al., 1998b), where some ripening-related phenomena such as softening occur, but other ripening-related processes such as flavor development and acceptable texture were compromised when fruit were processed at an excessively immature stage.

To deliver a longer shelf life, firmer, often less mature fruit may be processed by companies. Such a scenario is also much more common during the "off season," when imported melons are processed. However cubes prepared with less mature fruit, that are excessively firm, as clearly demonstrated within this study, lack flavor volatiles (Beaulieu, 2006) and have inferior, less acceptable sensory attributes (Beaulieu et al., 2004). Overall, and based on these quality data, it appears that high quality fresh-cut muskmelon can be prepared with fruit when harvested at least $1 / 2$-slip, but not from $1 / 4$-slip fruit. This is very significant concerning the acquisition of high-quality "ripe" offseason, nondomestic produce and postprocessing quality.

\section{Literature Cited}

Abbott, J.A. and F.R. Harker. 2004. Texture. In: K.C. Gross, C.Y. Wang, and M.E. Saltveit (eds.). USDA handbook no. 66. The commercial storage of fruits, vegetables, and florist and nursery stocks. 18 June 2007. <http://usna.usda.gov/hb66/021 texture.pdf $>$.

Aulenbach, B.B. and J.T. Worthington. 1974. Sensory evaluation of muskmelon: Is soluble solids content a good quality index? HortScience 9:136-137.

Bareuther, C.M. 2000. Magnifying melon sales. Produce Business May:60-68.

Beaulieu, J.C. 2005. Within-season volatile and quality differences in stored fresh-cut cantaloupe cultivars. J. Agr. Food Chem. 53:8679-8687. Beaulieu, J.C. 2006. Volatile changes in cantaloupe during growth, maturation and in stored fresh-cuts prepared from fruit harvested at various maturities. J. Amer. Soc. Hort. Sci. 131:127-139.

Beaulieu, J.C. and E.A. Baldwin. 2002. Flavor and aroma of fresh-cut fruits and vegetables, p. 391-425. In: O. Lamikanra (ed.). Fresh-cut fruits and vegetables. Science, technology and market. CRC Press, Boca Raton, FL.

Beaulieu, J.C. and J.R. Gorny. 2004. Fresh-cut fruits. In: K.C. Gross, C.Y. Wang, and M.E. Saltveit (eds.). USDA handbook no. 66. The commercial storage of fruits, vegetables, and florist and nursery stocks. 18 June 2007. <http://usna.usda.gov/hb66/146freshcut fruits.pdf $>$.

Beaulieu, J.C. and C.C. Grimm. 2001. Identification of volatile compounds in cantaloupe at various developmental stages using solid phase microextraction. J. Agr. Food Chem. 49:1345-1352.

Beaulieu, J.C., D.A. Ingram, J.M. Lea, and K.L. Bett-Garber. 2004. Effect of harvest maturity on the sensory characteristics of fresh-cut cantaloupe. J. Food Sci. 69:S250-S258.

Beaulieu, J.C. and J.M. Lea. 2003. Aroma volatile differences in commercial orange-fleshed cantaloupes, the inbred parental lines, and stored fresh-cuts. Acta Hort. 628:809-815.

Beaulieu, J.C., Z. Peralta-Inga, J.M. Lea, and G. Eggleston. 2003. Sugar and organic acid variations in commercial cantaloupes and their inbred parental lines. J. Amer. Soc. Hort. Sci. 128:531-536.

Bianco, V.V. and H.K. Pratt. 1977. Compositional changes in muskmelon during development and in response to ethylene treatment. J. Amer. Soc. Hort. Sci. 102:127-133.
Boynton, B.B., B.A. Welt, C.A. Sims, J.K. Brecht, M.O. Balaban, and M.R. Marshall. 2005. Effects of low-dose electron beam irradiation on respiration, microbiology, color, and texture of fresh-cut cantaloupe. HortScience 15:802-807.

Cantwell, M.I. and S.I. Portela. 1997. Comparing varieties \& storage methods. Fresh Cut 5:14-18.

Currence, T.M. and R. Larson. 1941. Refractive index as an estimate of quality between and within muskmelon fruits. Plant Physiol. 16:611-620.

Eggleston, G., A. Monge, and A. Pepperman. 2002. Preheating and incubation of cane juice prior to liming: A comparison of intermediate and cold lime clarification. J. Agr. Food Chem. 50:484-490.

Evensen, K.B. 1983. Effects of maturity at harvest, storage temperature, and cultivar on muskmelon quality. HortScience 18:907-908.

Gil, M.I., E. Aguayo, and A.A. Kader. 2006. Quality changes and nutrient retention in fresh-cut versus whole fruits during storage. J. Agr. Food Chem. 54:4284-4296.

Gorny, J.R., M.I. Gil, and A.A. Kader. 1998a. Postharvest physiology and quality maintenance of fresh-cut pears. Acta Hort. 464:231-236.

Gorny, J.R., B. Hess-Pierce, and A.A. Kader. 1998b. Effects of fruit ripeness and storage temperature on the deterioration rate of fresh-cut peach and nectarine slices. HortScience 33:110-113.

Hoover, M.W. 1955. Preliminary studies relating to the effect of maturity and storage treatments upon the quality of cantaloupes. Proc. Fla. State Hort. Soc. 68:185-188.

Hubbard, N.L., S.C. Huber, and D.M. Pharr. 1989. Sucrose phosphate synthase and acid invertase as determinants of sucrose concentration in developing muskmelon (Cucumis melo L.) fruits. Plant Physiol. 91:1527-1534.

Lamikanra, O., J.C. Chen, D. Banks, and P.A. Hunter. 2000. Biochemical and microbial changes during the storage of minimally processed cantaloupe. J. Agr. Food Chem. 48:5955-5961.

Lange, D. 1998. Eastern cantaloupe varieties and their potential for fresh-cut melon products. Fresh Cut 6:17-18.

Lester, G.E. 1990. Lipoxygenase activity of hypodermal and middle mesocarp tissue from netted muskmelon fruit during maturation and storage. J. Amer. Soc. Hort. Sci. 115:612-615.

Lester, G.E. 1998. Physicochemical characterization of hybrid honey dew muskmelon fruit (Cucumis melo L. var. inodorus Naud.) following maturation, abscission and postharvest storage. J. Amer. Soc. Hort. Sci. 123:126-129.

Lester, G.E., L.S. Arias, and M. Gomez-Lim. 2001. Muskmelon fruit soluble acid invertase and sucrose phosphate synthase activity and polypeptide profiles during growth and maturation. J. Amer. Soc. Hort. Sci. 126:33-36.

Lester, G.E. and J.R. Dunlap. 1985. Physiological changes during development and ripening of 'Perlita' muskmelon fruits. Sci. Hort. 26:323-331.

Luna-Guzmán, I. and D.M. Barrett. 2000. Comparison of calcium chloride and calcium lactate effectiveness in maintaining shelf stability and quality of fresh-cut cantaloupes. Postharvest Biol. Technol. 19:61-72.

McCollum, T.G., D.J. Huber, and D.J. Cantliffe. 1988. Soluble sugar accumulation and activity of related enzymes during muskmelon fruit development. J. Amer. Soc. Hort. Sci. 113:399-403.

Mizuno, T., K. Kato, M. Harada, Y. Miyajima, and E. Suzuki. 1971. Studies on the free sugars and amino acids in a fruit of muskmelon. J. Jpn. Soc. Food Sci. Technol. 18:319-325.

Mutton, L.L., B.R. Cullis, and A.B. Blakeney. 1981. The objective definition of eating quality in rockmelons (Cucumis melo). J. Sci. Food Agr. 32:385-391.

Ogle, W.L. and E.P. Christopher. 1957. The influence of maturity, temperature, and duration of storage on quality of cantaloupes. Proc. Amer. Soc. Hort. Sci. 70:319-324.

Pratt, H.K. 1971. Melons, p. 207-232. In: A.C. Hulme (ed.). The biochemistry of fruits and their products. Academic Press, New York.

Pratt, H.K., J.D. Goesschl, and F.W. Martin. 1977. Fruit growth and development, ripening and role of ethylene in the 'Honey Dew' muskmelon. J. Amer. Soc. Hort. Sci. 102:203-210. 
Produce Marketing Association. 2005. Fresh-cut produce industry. Technical report. Produce Marketing Association Member Service, Newark, DE.

Shalit, M., N. Katzir, Y. Tadmor, O. Larkov, Y. Burger, F. Shalekhet, E. Lastochkin, U. Ravid, O. Amar, M. Edelstein, Z. Karchi, and E. Lewinsohn. 2001. Acetyl-CoA: Alcohol acetyltransferase activity and aroma formation in ripening melon fruits. J. Agr. Food Chem. 49:794-799.

Stepansky, A., I. Kovalski, A.A. Schaffer, and R. Perl-Treves. 1999. Variation in sugar levels and invertase activity in mature fruit representing a broad spectrum of Cucumis melo genotypes. Genet. Resour. Crop Evol. 46:53-62.

Toivonen, P.M.A. and J.R. DeEll. 2002. Physiology of fresh-cut fruits and vegetables, p. 91-123. In: O. Lamikanra (ed.). Fresh-cut fruits and vegetables. Science, technology and market. CRC Press, Boca Raton, FL.

U.S. Department of Agriculture. 2006. USDA National Nutrient Database for Standard Reference, release 19. 18 June 2007. $<$ http://www.ars.usda.gov/Main/docs.htm?docid=4451>.

Waldron, K.W., M.L. Parker, and A.C. Smith. 2003. Plant cell walls and food quality. Comprehensive Rev. Food Sci. Food Safety 2: $101-119$.
Wang, Y., S.G. Wyllie, and D.N. Leach. 1996. Chemical changes during the development and ripening of the fruit of Cucumis melo (cv. Makdimon). J. Agr. Food Chem. 44:210-216.

Watada, A.E., K. Abe, and N. Yamuchi. 1990. Physiological activities of partially processed fruits and vegetables. Food Technol. 44:116-122.

Watada, A.E. and L. Qi. 1999. Quality of fresh-cut produce. Postharvest Biol. Technol. 15:201-205.

Western Farm Express. 2003. Fresh-cut vegetable, fruit sales show growth. Western Grower 25:21-23.

Wiley, R.C. 1994. Minimally processed refrigerated fruits \& vegetables. Chapman \& Hall, London.

Wyllie, S.G., D.N. Leach, and Y. Wang. 1996. Development of flavor attributes in the fruit of $C$. melo during ripening and storage and storage, p. 228-239. In: G.R. Takeoka, R. Teranishi, P.J. Williams, and A. Kobayashi (eds.). Biotechnology for improved foods and flavors. American Chemical Society, Washington, DC.

Yamaguchi, M., D.L. Hughes, K. Yabumoto, and W.G. Jennings. 1977. Quality of cantaloupe muskmelons: Variability and attributes. Sci. Hort. 6:59-70.

Zapata, S. and J.P. Dufour. 1992. Ascorbic, dehydroascorbic and isoascorbic acid simultaneous determinations by reverse phase ion interaction HPLC. J. Food Sci. 57:506-511. 